\title{
NEO-ORIENTALISM AND THE NEO-IMPERIALISM THESIS: POST-9/11 US AND ARAB WORLD RELATIONSHIP
}

\author{
Mubarak Altwaiji
}

\begin{abstract}
Post-9/11 American neo-Orientalist representations pervade today's politics and journalism about the Arab World. Since the first emergence of the Middle East representation in American writings of the nineteenth century, one can assume that nothing has changed in representations of the Middle East in the US. This article explores a twenty-first century phenomenon called "neo-Orientalism," a style of representation that, while indebted to classical Orientalism, focuses on "othering" the Arab world with the exclusion of some geographic parts, such as India and Turkey, from the classical map of Orientalism. Although neo-Orientalism represents a shift in the selection of its subject and locale, it nonetheless reproduces certain repetitions of and conceptual continuities with its precursor. Like classical Orientalism, neo-Orientalism is a monolithic discourse based on binarism between the superior American values and the inferior Arab culture.
\end{abstract}

Keywords: post 9/11, terrorist attacks, neo-Orientalism, imperialism, terrorism, Arab, America, culture

\section{A Move from Orientalism to Neo-Orientalism?}

\section{The East is a career \\ Benjamin Disraeli}

The terrorist attacks of 9/11 had and continued to have an enormous impact on global politics in general and Arab-American relationship in particular. Some critics suggested the year 2001 a "year zero" or a "transformative moment" in Arab-American relationship in which the Americans see Arab Muslims as fanatical, violent, and lacking in tolerance. On the other hand, Arab Muslims see the Americans as selfish, immoral, and greedy as well as violent and fanatical (Barzegar, 2005: 115). 2001 has inaugurated a century of practicing symbolic power on the perpetrators, the Arab world. ${ }^{1}$ This symbolic power usually refers to a power used by the empire to create a hegemonic version of reality (Bourdieu, 1996: 41). The production of reality in this sense is the means to produce distorted

\footnotetext{
Mubarak Altwaiji is a research fellow at Goa University, Goa, India.
} 
images of dominated people, and because of generalizing the term "terrorism," Arab Muslims are victims of symbolic power in two ways. The first is the "terrorist" propagation, with which the imperial stereotyping power has labeled all Arab Muslims, if not all Arabs including the Christian Arabs. The second way is described by Ishmael, a major Arab character in Leon Uris' (1984: 15) novel The Haj:

So before I was nine I had learned the basic canon of Arab life. It was me against my brother; me and my brother against our father; my family against my cousins and the clan; the clan against the tribe; and the tribe against the world. And all of us against the infidel.

The most important effect of the $9 / 11$ attacks on the American classical Orientalist academia is the injection of a "neo" dynamism to the political arena and issues related to the Arab world, the most static and dictatorial region of the world. The Orient, in the nineteenth-century European usage of the word, refers to the East which comprises "Arabs, Turks, and Indians" (Lewis and Wigen, 1997: 54). Since the publication of Orientalism in 1978, world political relationships and political interests changed dramatically. Simultaneously the term "Orient" has been influenced by escalating waves of global political changes, and thus its geography is reconsidered and reshaped accordingly. The 9/11 terrorist attacks, the American military retaliation, and world politics changes contributed to the re-evaluation of the classic Orient (Merskin, 2004: 161). Therefore, the 9/11 attacks have been a global symbolic event marked by American retaliation acts, changing East-West relationship, and world politics changes. The result of this symbolic change is the emergence of the neo-Orientalist academia in which the Arab world becomes the center while major classic components such as India, Iran, and Turkey are excluded from the neo-Orientalist map.

If the world politics changed after the 9/11 terrorist attacks, political statements and views also changed, and therefore, representing the neo-Orient at this period is a reflection of its political context and social feelings (Sanderson and Nikitin, 2006: 33). Similarly, political and cultural production of this period situates the American views in history and exposes the ways in which historical contexts influence the production of meanings. Neo-Orientalism is more tied to the post-9/11 American cultural changes and the retaliation that took place after the attacks. The 9/11 attacks and the so-called "War on Terror" brought the Middle East and the classic Orientalist discourse, with its binary division of "us" and "them" into focus once more. Therefore, representations of Arab Muslims become more prevalent in post-9/11 politics, and terrorism becomes the most available term for labeling this group of people. The war on terrorism does not only involve a fight against Arab terrorists but also dedicates great efforts for observing and keeping an eye on 
every Muslim as the Canadian Prime Minister said on September 6, 2011, "Islamic terrorism is the greatest threat to Canada's security" (CBC News, 2011). This view, including American assumptions spanning many fields of cultural studies, assumes that Islam is a threat to the Western way of life.

9/11 is a living reality for all Americans who faced up to terror and represented this horrible event in their own ways. On September 11, 2001, former US Secretary of State Lawrence Eagleburger commented to CNN, "There is only one way to begin to deal with people like this, and that is you have to kill some of them even if they are not immediately directly involved in this thing" (Fairness \& Accuracy in Reporting, 2001). On September 13, Bill O'Reilly, a prominent American television host, articulated his opinion to the Fox News Channel, "[I]t doesn't make any difference who you kill in the process of retaliation against the attacks" (Fairness \& Accuracy in Reporting, 2001). On the same day, Ann Coulter, an American lawyer, wrote in Universal Press Syndicate, "This is no time to be precious about locating the exact individuals directly involved in this particular terrorist attack ... We should invade their countries, kill their leaders and convert them to Christianity" (Fairness \& Accuracy in Reporting, 2001). The American media has accepted the side effects of a stigmatization of Islam, Islamic states, and the Muslims and paved the way for prejudices and offensive statements appearing regularly in televised interviews with leading politicians.

The US policy makers have defined the American national security and strategic interests as "ensuring access to Middle East oil, containing any aspiring regional hegemonic powers, and limiting the proliferation of weapons of mass destruction" (Hadar and Preble, 2008: 539). After 9/11 attacks, the American policy toward the Middle East changed dramatically. Since the 9/11 terrorist attacks, the US has been trying to achieve a complex set of goals through a network of formal and informal strategies through both direct military and cultural confrontations. In an interview with Geov Parrish, Chomsky (2006) notes that the US administration has limitedly used force to avenge its sovereignty by invading Iraq though Iraq has nothing to do with 9/11:

If its main product was lettuce and pickles ... If you have three gray cells functioning, you know ... The U.S. invaded Iraq because it has enormous oil resources, mostly untapped, and it's right in the heart of the world's energy system. Which means that if the U.S. manages to control Iraq, it extends enormously its strategic power ... over Europe and Asia.

It is all about hegemony or what Zbigniew Brzezinski (2003: 8) calls its "political and cultural critical leverage" on the Middle East region. This hegemony is encapsulated in the 1990 statement of Dick Cheney on hegemony on the Gulf region: "Whoever controls the flow of Persian Gulf oil has a stranglehold not only 
on our economy but also on the other countries of the world as well" (Vallely, 2004: 45).

\section{The Neo-Orientalism Thesis}

What is meant by neo-Orientalism? Dag Tuastad (2003: 595) has used the term to criticize the American neo-colonial and neo-liberal agenda in the Middle East and the superiority of the American values. The inauguration of a new academia of Orientalism is clearly seen in the cultural and political hegemonic statements of prominent Western leaders who define their countries and culture in relation to the East and its culture. The inauguration of neo-Orientalism was successfully indicated when George W. Bush described the American "war on terrorism" as a "crusade" on September 16, 2001, and his wife gave her opinion about issues of terrorism and the rights of Muslim women on November17, 2001: "Yet the terrorists who helped rule that country now plot and plan in many countries. And they must be stopped. The fight against terrorism is also a fight for the rights and dignity of women" (Bush, 2001). This neo-Orientalism binarism becomes accepted in other Western countries and is generalized in most of the statements of Western leaders who give their views on the East and its culture. The statement of the former Italian Prime Minister Silvio Berlusconi on September 16, 2001, "we should be conscious of the superiority of our civilization" (Hooper and Connolly, 2001) and the Canadian prime minister's statement "Islamic terrorism is the greatest threat to Canada's security" are examples of this accepted norm $(C B C$ News, 2011). These views, including the whole Western assumptions spanning many fields of cultural studies, assume that the East is a source of threat to the Western way of life.

A critical reading of post-9/11 neo-Orientalist statements would question the way the influences of neo-colonialism and neo-imperialism are ignored, as well as the reductionist approach of identifying Islam, the world's fastest growing religion, as anti-modern and anti-West religion. The basic tenets of American Orientalism are identified in a famous American anthology written by leading US neo-Orientalists and social scientists: "Culture Matters: How Values Shape Human Progress." In this book, Arab culture is introduced to readers as "Islamic culture," and Islam is looked at as a dependent variable that explains the level of Arabic antagonisms from Western values (Harrison and Huntington, 2000: xiv). Similarly, the whole Islamic world suffers the same cultural crisis because Islam is an integral part of daily life in most of these societies where "[d]emocratic institutions are commonly weak or nonexistent" compared with Latin American countries whose "[d]emocracy has prospered in the past fifteen years" (Harrison 
and Huntington, 2000: xix). In these societies, the authors argue, religion hinders progress and confines the people to traditions:

The pace of modernization in most Islamic countries has been slow. Illiteracy, particularly among women, is still very high in many of them, as are child mortality and population growth ... Turkey is the only Islamic country-secular, to be sure-that approaches modern standards of pluralistic governance. Malaysia is relatively prosperous, but its economic gains disproportionately reflect the economic creativity of its large Chinese (32 percent of the total population) minority. (Harrison and Huntington, 2000: 301)

How is the neo-Orientalism produced? In Covering Islam: How the Media and the Experts Determine How We See the Rest of the World, Edward Said (1997: 55) argued that "Islam represents a resurgent atavism, which suggests not only the threat of a return to the Middle ages but the destruction of what is regularly referred to as the democratic order in the western world." If this is the image of Islam before the $9 / 11$ attacks, the Western perception of this religion has worsened. Like classic Orientalism, neo-Orientalism is a fact and could be the new avatar of Orientalism because Orientalism is very much "tied to the tumultuous dynamics of contemporary history" (Said, 1978: xiv). Unlike the classic Orientalism that represents different issues of different ethnic groups of the Middle East, neoOrientalism is distinguished by the geography it covers which Said defines as "Islamic East v. the West" (Said, 1978: xvi).

In the 2003 preface to his book Orientalism, Said identified the twenty-first century Orientalism as "belligerent neo-Orientalism" (Said, 1978: xxi). This belligerent academia dominated the early post-9/11 American political views and media statements on Arab Muslims' identity as an individual actor and Islam as an institution. This hegemonic production can be the means to generate "distorted images of dominated people" (Tuastad, 2003: 591). Accordingly, Arab Muslims in neo-Orientalist discourse are subjects of distortion in two ways. The first is the terrorist stigma with which the neo-Orientalist legacy/superiority/authority has labeled radical Islamic groups, if not the whole Arab Muslims of the Middle East. The second description is the imagery of Arab mentality which Said (1978: 309-310) quotes in Orientalism:

The Arabs so far have demonstrated an incapacity for disciplined and abiding unity. They experience collective outbursts of enthusiasm but do not pursue patiently collective endeavors, which are usually embraced half-heartedly. They show lack of coordination and harmony in organization and function, nor have they revealed an ability for cooperation. Any collective action for common benefit or mutual profit is alien to them ... The Arabs exist only as an occasion for the tyrannical observer. 
Bernard Lewis (2004: 16), a chief proponent of what has been called neoOrientalism, mirrors Daniel Pipes and Samuel Huntington in an informative way by attributing terrorism to the Islamic hatred of the West in his The Crisis of Islam: Holy War and Unholy Terror: "the resentments that dominated the Islamic world today and that are increasingly expressed in acts of terrorism." Bernard Lewis can be taken as the best example of American neo-Orientalism because he can be a very good link between the paradigms of Orientalism and neo-Orientalism. His recent books What Went Wrong? The Clash Between Islam and Modernity in the Middle East (Lewis, 2003) and The Crisis of Islam: Holy War and Unholy Terror (Lewis, 2004) were New York Times bestsellers and National bestsellers. In What Went Wrong? Lewis highlights the deterioration of Islamic values and the rise of Western intellectualism and Enlightenment. Lewis asserts the superiority of the Western civilization when he speaks of the "most profound single difference" between Islamic and Western civilizations to be the status of women: "according to Islamic law and tradition, there were three groups of people who did not benefit from the general Muslim principle of legal and religious quality-unbelievers, slaves, and women" (Lewis, 2003: 67). According to Lewis, woman in Islam is the "worst-placed of the three," because "the slave could be freed by his master; the unbeliever could at any time become a believer by his own choice, and thus end his inferiority," but "only the woman was doomed forever to remain what she was" (Lewis, 2003: 69).

Lewis' interpretation of Islam and Muslims in his bestseller books is partly responsible for the current increase in the American antipathy toward Arab Muslims. His interpretations could be also responsible for post-9/11 extremist statements against Arab Muslims. A Lewis-type portrait of Islam can lead people such as Fred Ikle, a neoconservative strategist and former undersecretary of defense, to mix up a terrorist group with 1.3 billion Muslim populations: "A nuclear war stirred up against the 'infidels' might end up displacing Mecca and Medina with two large radioactive craters" (Ikle, 2002). Similarly, Lewisism leads the American evangelical Christians like Jerry Falwell to thunder against Islam and its Prophet: "I think Mohammed was a terrorist ... I have read enough of the history of his life, written by both Muslims and non-Muslims, that he was about a violent man, a man of war" (Harris, 2002). These offensive opinions about the founder of Islam are expressed by Pat Robertson, a conservative Christian and founder of the Christian Coalition: "This man was an absolute wild-eyed fanatic ... He was a robber and a brigand. And to say that these terrorists distort Islam? They're carrying out Islam! ... Adolph Hitler was bad, but what the Muslims want to do to the Jews is worse" (Harris, 2002). Such intensive focus on the Arab world plays an important role in foregrounding issues related to Muslims in the American public domain after the terrorist attacks of 9/11. Ten months after 9/11 at a meeting 
of the Global Policy Forum that aimed at providing a picture of how the world has been portrayed, Directorate of Berghof Conflict Research criticizes the American media for how it fully attributed blame for the September attacks on the Muslims in general and stopped there.

Said (1997) describes Lewis as "one of the worst offenders in the cultural war against Islam" (xxix). In addition, Said (1978: 318) writes in Orientalism,

Lewis's polemical, not scholarly, purpose is to show, here and elsewhere, that Islam is an anti-Semitic ideology, not merely a religion ... Islam is an irrational herd or mass phenomenon, ruling Muslims by passions, instincts, and unreflecting hatreds. The whole point of his exposition is to frighten his audience, to make it never yield an inch to Islam. According to Lewis, Islam does not develop, and neither do Muslims; they merely are, and they are to be watched, on account of that pure essence of theirs (according to Lewis), which happens to include a long-standing hatred of Christians and Jews.

Moreover, Lewis has been one of the most reliable advisors to the American administration in the post-9/11 American war on terrorism. Like Daniel Pipes (2008) who affirms "Muslim countries have the most terrorists and the fewest democracies in the world," Lewis (2004: xxxii) asserts the inherent terrorist nature of the Muslims in The Crisis of Islam-Holy War and Unholy Terror: "[S]ignificant numbers of Muslims are ready to approve, and a few of them to apply, this [extremist] interpretation of their religion. Terrorism requires only a few. Obviously the West must defend itself by whatever means will be effective." Lewis, however, did not mention how he managed to count the number of the Muslims who can be easily involved in terrorist acts or "ready to approve" it.

\section{New Imperialism}

Dag Tuastad (2003: 594) opines that American new imperialism in the Middle East goes along with the neo-Orientalist discourse that highlights the violence of the Arabs. He calls modern American representation of Arab violence "new barbarism." The new barbarism image is an essential component of neoOrientalist discourse in which the violence of the Middle East threatens the world. This violence is an embedded part of the local culture. The barbarism of the Arabs is interwoven with post-9/11 neo-Orientalist imaginaries to facilitate new imperialist strategies that aim at dominating new regions like Iraq and legitimize the continuous political and economic hegemony on the small Gulf countries: " $t \mathrm{t}]$ he pursuit of oil has long constituted the most commanding motive for US military action in the Persian Gulf region" (Klare, 2002). Representation of the Arab barbarism resonates clearly within the post-9/11 American political discourse. In a meeting with the Palestinian politician Nabil Shaath, George W. Bush claimed that 
he was on a mission from God when he launched the invasions of Afghanistan and Iraq. Bush's speech on the invasion of Iraq is more colored by divine and moral authority than imperial interests, a language that convinces a broader audience of the necessity of military action in that violent part of the Middle East:

I'm driven with a mission from God. God would tell me, "George, go and fight those terrorists in Afghanistan." And I did, and then God would tell me, "George, go and end the tyranny in Iraq." And I did. And now, again, I feel God's words coming to me, "Go get the Palestinians their state and get the Israelis their security, and get peace in the Middle East." And by God I'm gonna do it. (Sturcke, 2005)

The foremost important point for understanding the invasion of Iraq is the American grand strategy launched by George W. Bush to undertake a coercive assertion of global hegemony. ${ }^{2}$ In his response to the 9/11 attacks, Bush's administration and the National Security Strategy make explicit the coercive turn, the "full spectrum dominance,"3 a strategy which allows full dominance on Iraq without the approval of the United Nations. The dominance on Iraq is pivotal and the basic pillar in the strategy of the US in "reshaping the Middle East" and "securing US hegemony in the Middle East" and dominating "the world oil reserves" (Hinnebusch, 2007: 220). Of course, the invasion of Iraq has been fueled by many claims such as the Iraqi link with Al-Qaida and developing weapons of mass destruction to use against the US, and hence Iraq represented an imminent threat to the US and the whole West. Even if there were no strong evidences to support these claims, the US, at any rate, needed to exaggerate them to maintain freedom of action in the Middle East. In an interview with Iran's Press TV, Noam Chomsky (2010) states that the wars launched in response to the $9 / 11$ attacks are "criminal." He further questions and shows doubts in the whole story of $9 / 11$ terrorist attacks:

We later discovered one of the reasons why they did not bring evidence: they did not have any ... Eight months later, the head of the FBI informed the press that the FBI believed that the plot may have been hatched in Afghanistan, but was probably implemented in the United Arab Emirates and Germany ... So they had no evidence. (Chomsky, 2010)

In the book Hegemony or Survival: America's Quest for Global Dominance, Chomsky (2003: 153) notes that the invasion of Iraq has nothing to do with the retaliation to the 9/11 terrorist attacks: "The basic principle is that hegemony is more important than survival." Chomsky (2003: 83) explains the hegemonic interests of the US by quoting the senior Middle East correspondent and analyst Youssef Ibrahim's statement “turning a 'friendly' Iraq into a private American oil pumping station." Therefore, ensuring oil supply to the US is a part of the American hegemony on Arabia. For this purpose, democracy and enhancing human rights 
are used as a cover for American military existence in the region. On November 15, 2002, Donald Rumsfeld, a former American Defense Secretary, states, "The Iraq war has nothing to do with oil, literally nothing to do" (Esterbrook, 2002). This statement of Rumsfeld is contradicted by his deputy, Paul Wolfowitz, a few months later in 2003 as he states, "Let's look at it simply. The most important difference between North Korea and Iraq is that economically, we just had no choice in Iraq. The country swims on a sea of oil" (Wright, 2003).

Therefore, fighting tyranny in the Middle East, barbarism, and the aggressive nature of the local culture are the basic tenets of neo-Orientalism though the propagated message of this academia denies the relevance of hegemony. As classic Orientalism once served the policies of European colonial powers, neoOrientalism serves the political hegemony and neo-colonial interests of people who are aware of the need to produce images of aggression and terrorism on the targeted nation. This hegemony on the Orient is generally accepted as a fact even before the neo-Orientalist discourse is produced. However, it is only after the 9/11 attacks the American policy toward the East is in question because the Arab world becomes the main centerpiece of the American drive for global hegemony.

\section{Notes}

1. Symbolic power accounts for discipline used against the other to confirm that individual's placement in a social hierarchy. It is also referred to as "soft" power, and symbolic power includes actions that have discriminatory or injurious meaning or implications, such as gender dominance and racism. While symbolic power requires a dominator, it also requires the dominated to accept their position in the exchange of social value that occurs between them.

2. Grand strategy, also called high strategy, comprises the purposeful employment of all instruments of power available to a security community. The role of grand strategy is to co-ordinate and direct all the resources of a nation, or band of nations, toward the attainment of the political object of the war-the goal defined by fundamental policy.

3. Full-spectrum dominance is where a military structure achieves control over all elements of the battle space using land-based (http://en.wikipedia.org/wiki/Land_warfare), air-based (http:// en.wikipedia.org/wiki/Air_warfare), maritime-based (http://en.wikipedia.org/wiki/Naval_warfare), space-based (http://en.wikipedia.org/wiki/Space_warfare), and cyber-based (http://en.wikipedia. org/wiki/Cyber_warfare) assets. Full-spectrum dominance includes the physical battle space, air, surface, and sub-surface as well as the electromagnetic spectrum and information space (http:// en.wikipedia.org/wiki/Information_warfare). Control implies that freedom of opposition force assets to exploit the battle space is wholly constrained.

\section{References}

Barzegar, K. (2005). The Middle East and the "New Terrorism." Journal on Science and World Affairs, 1(2), 113-121.

Bourdieu, P. (1996). Symbolsk makt. Oslo: Pax forlag.

Brzezinski, Z. (2003). Hegemonic Quicksand. The National Interest, No. 74, 5-16. 
Bush, L. (2001). "Radio Address by Laura Bush to the Nation." C-SPAN. Web. Accessed February 8, 2014. <http://www.c-span.org/video/?167373-1/first-lady-radio-address>.

CBC News. (2011). "Harper says 'Islamicism' biggest threat to Canada'." CBC News, September 6. Web. Accessed October 15, 2014. <http://www.cbc.ca/news/politics/harper-says-islamicism-biggest-threat-to-canada-1.1048280>.

Chomsky, N. (2003). Hegemony or Survival: America's Quest for Global Dominance. New York: Henry Holt and Company.

Chomsky, N. (2006). "There Is No War on Terror, Interview with Geov Parrish." AlertNet. Web. Accessed February 9, 2014. <http://www.alternet.org/story/30487/chomsky\%3A_'there_is_no_ war_on_terror>.

Chomsky, N. (2010). "No Evidence Provided for 9/11 War, Interview with Iran Press TV." IranPresstv.com, November 6. Web. Accessed February 4, 2014. <http://www.youtube.com/ watch? $=$ uzNhAo1zBD4>.

Esterbrook, J. (2002). "Rumsfeld: It Would Be a Short War." CBS News, November 15. Web. Accessed April 23, 2014. <http://www.cbsnews.com/news/rumsfeld-it-would-be-a-short-war/>.

Fairness \& Accuracy in Reporting. (2001). "Media March to War." FAIR, September 17. Web. Accessed April 24, 2014. <http://fair.org/press-release/media-march-to-war/>.

Hadar, L. and Preble, C. (2008). U.S. Policy in the Middle East. In Cato Handbook for Policymakers, ed. D. Boaz, pp. 539-547. Washington, DC: CATO Institute.

Harris, D. (2002). "Evangelical Christians Take Aim at Islam." ABC News, November 18. Web. Accessed April 24, 2014. <http://abcnews.go.com/WNT/Beliefs/story?id=130008>.

Harrison, L. E. and Huntington, S. P. (Ed.). (2000). Cultural Matters: How Values Shape Human Progress. New York: Basic Books.

Hinnebusch, R. (2007). American Invasion of Iraq: Causes and Consequences. Critique: Critical Middle Eastern Studies, 16(3), 209-228.

Hooper, J. and Connolly, K. (2001). "Berlusconi Breaks Ranks over Islam.” The Guardian, September 27. Web. Accessed April 23, 2014. <http://www.theguardian.com/world/2001/sep/27/afghanistan. terrorism7>.

Ikle, F. (2002). "Stopping the Next Sept. 11." The Wall Street Journal, June 2. Web. Accessed April 24, 2014. <http://csis.org/images/stories/ikle/047.2002WSJ.pdf>.

Klare, M. T. (2002). "Washington's Oilpolitik." Current History, July 18. Web. Accessed January 20, 2014. <http://www.salon.com/>.

Lewis, B. (2003). What Went Wrong? The Clash between Islam and Modernity in the Middle East. New York: Harper Perennial.

Lewis, B. (2004). The Crisis of Islam-Holy War and Unholy Terror. London: Phoenix.

Lewis, M. W. and Wigen, K. E. (1997). The Myth of Continents: A Critique of Metageography. Oakland, CA: University of California Press.

Merskin, D. (2004). The Construction of Arabs as Enemies: Post-September 11 Discourse of George W. Bush. Mass Communication and Society, 7(2), 157-175.

Pipes, D. (2008). "The Problem with Middle East Studies: A Microscopic Investigation." History News Network, July 14. Web. Accessed April 24, 2014. <http://www.danielpipes.org/5743/the-problemwith-middle-east-studies>.

Rumsfeld, D. (2002). "It Would Be a Short War." CBSnews.com, November 15. Web. Accessed April 23, 2014. <http://www.cbsnews.com/news/rumsfeld-it-would-be-a-short-war/>.

Said, E. W. (1978). Orientalism. New York: Pantheon Books.

Said, E. W. (1997). Covering Islam: How the Media and the Experts Determine How We See the Rest of the World. London: Vintage Books.

Sanderson, T. and Nikitin, M. B. (2006). International Cooperation. In Five Years after 9/11: An Assessment of America's War on Terror, ed. J. Smith and T. Sanderson, pp. 33-42. Washington, DC: Centre for Strategic and International Studies.

Sturcke, J. (2005). "White House Denies Bush God Claims." The Guardian, October 7. Web. Accessed April 25, 2014. <http://www.theguardian.com/world/2005/oct/07/usa.jamessturcke>. 
Tuastad, D. (2003). Neo-Orientalism and the New Barbarism Thesis: Aspects of Symbolic Violence in the Middle East Conflict(s). Third World Quarterly, 24(4), 591-599.

Uris, L. (1984). The Haj. New York: Bantam Books.

Vallely, P. (2004). The Fifth Crusade: George Bush and the Christianization of the War in Iraq. In Re-imagining Security, ed. A. Crooke, B. Milton-Edwards, M. Kaldor and P. Vallely, pp. 42-68. London: British Council.

Wright, G. (2003). "Wolfowitz: Iraq War Was about Oil." The Guardian, June 4. Web. Accessed February 5, 2014. <http://whatreallyhappened.com/WRHARTICLES/aboutoil.htm>. 